\title{
HEPATITIS C VIRUS;
}

SENSITIVITY OF ANTI HEPATITIS C VIRUS ANTIBODIES THRU ELISA METHOD IN COMPARISON TO HEPATITIS C VIRUS RIBONUCLEIC ACID BY PCR METHOD.

1. MD,

Senior Registrar,

Department of Medicine,

Peoples University of Medical and Health Sciences Nawabshah, Sindh, Pakistan.

2. FCPS

Assistant Professor

Department of Medicine,

Peoples University of Medical and

Health Sciences Nawabshah, Sindh, Pakistan.

3. M. Phil

Assistant Professor

Biochemistry Department,

Peoples University of Medical and Health Sciences Nawabshah,

Sindh, Pakistan.

Correspondence Address:

Dr. Ghulam Mustafa Jamali

Senior Registrar,

PUMHS, Nawabshah.

dr_mustafa_jamali72@yahoo.com

Article received on:

18/04/2017

Accepted for publication:

15/09/2017

Received after proof reading:

03/11/2017
Ghulam Mustafa Jamali ${ }^{1}$, Anwar Ali Jamali², Habibullah Shaikh ${ }^{3}$

ABSTRACT... Objectives: The plan of this current research was in the direction for towards the assessment of the existing ELISA (Enzyme Linked Immunosorbant Assay) method through antibodies testing for identification of hepatitis $C$ virus disease by comparing their outcome with the Real Time polymerase chain reaction analysis. Setting: Peoples Medical College Hospital Nawabshah. Period: December 2015 to December 2016. Methods: In this current research 100 blood samples were analyzed due to the presence of anti-HCV antibodies by 3rd-generation enzyme-linked immunosorbent assay testing. All the specimens were $100 \%$ positive. Polymerase chain reaction test was performed according to the laboratory directions in anti- hepatitis $C$ virus antibodies positive patients to validate the diagnosis of hepatitis $C$ virus infectivity. Results: This research shows that, the entire results were positive by Enzyme Linked Immunosorbant Assay testing. As compared with polymerase chain reaction the of Enzyme Linked Immunosorbant Assay in this research the screening test for anti hepatitis $C$ virus - antibodies is about $2 \%$ false positive. Out of the 100 samples 98 cases are positive by Real Time polymerase chain reaction analysis while only 02 cases report are negative (2\%). Conclusion: The proportion of hepatitis C virus infectivity was $100 \%$ by 3rd-generation enzyme-linked immunosorbent assay testing, $98 \%$ by Real Time polymerase chain reaction analysis. As in our research the hepatitis $C$ virus - Ribonucleic acid is present in $98 \%$ cases who are the Anti- hepatitis $C$ virus antibodies positive patients, it can be suggested that Anti-HCV antibodies detection by third generation ELISA technique in routine procedure is sufficient to determine HCV infection.

Key words: $\quad$ Anti-hepatitis C virus Antibodies, Hepatitis C Virus - Polymerase Chain Reaction, ELISA, HCV.

Article Citation: Jamali GM, Jamali AA, Shaikh H. Hepatitis C Virus; Sensitivity of anti hepatitis $\mathrm{c}$ virus antibodies thru elisa method in comparison to hepatitis $\mathrm{C}$ virus ribonucleic acid by pcr method. Professional Med J 2017;24(11):16211629. DOI:10.17957/TPMJ/17.3985

\section{INTRODUCTION}

Pakistan is endemic country for viral infection $\mathrm{HCV}$ with increasing load of illness is expected to rise in the fore coming years because of unsafe and hurried medical professional skills. The HCV prevalence in Pakistan had been reviewed previously time to time. Approximately about eighty six related researches done up-todate through literature search conducted here. So therefore an updated analysis for revision is needed for the integration of the recent data. The sero-prevalence of $\mathrm{HCV}$ is $6.8 \%$, while active $\mathrm{HCV}$ infection was found in approximately $6 \%$ among the general adult Pakistani residents data published between 2010 and 2015. Studies has concluded that elevated Hepatitis $C$ Virus frequency equal to 25percent in Pakistani peoples.
Viral hepatitis due to HCV is a most important notorious international healthiness distress among Infection. It is to be estimated that about 17 hundred lac human beings have been suffering from Hepatitis C Virus throughout the world; the burden of this disease is continuously on the rise in many countries of world affecting the economic, social and health of people's at large scales. ${ }^{2,3}$

On the other hand the occurrence of Hepatitis $C$ Virus infection is on its last legs in most developed countries of world since past twenty years lowest in Americas, Australia the and Western Europe, highest in eastern Mediterranean and African areas. ${ }^{4-10}$ 
Hepatitis C Virus is a part of the Flaviviridae family RNA genome with positive sense, singlestranded virus with an approximately $9.6 \mathrm{~kb}$. Because of poor fidelity of HCV there is elevated point of series heterogeneity in dependent-RNApolymerase chain proteins like NS5B protein. ${ }^{11}$ There are about six identified HCV genotypes as genotype-1to genotype -6 , in parallel to that many different sub-types have been recognized based on series homology. ${ }^{12}$

In the last stage hepatocellular carcinoma there is great demand in favor of liver transplantation because of Hepatitis $C$ is the most important root cause for hepatic complications, next to 2030 the rate of recurrence of these is predictable with possibility of raise twice or thrice fold. Transmission is mainly thru with the intravenous drug abuse, infected blood products, perinatal infection, and unintentional syringe or other injectable device penetration, additional fewer frequent modes like thru sex and from mother to fetus spread are identified. ${ }^{13}$

It is necessary to identify the infection of HCV active infection thru authentic laboratory evidence for confirmation of the disease, because of the simultaneous threat of disturbance to life with death and also risk of pharmacology-induced / spontaneous persistent treatment of virus for healthy life. Various practical methods are accessible for the confirmation and treatment of $\mathrm{HCV}$ disease they comprise:

1. Antibodies in Serum to identify HCV.

2. To identify and compute RNA of HCV thru advance laboratory analysis.

3. To identify Genes for different typing methods.

For to identify and measure core antigen of HCV different techniques are available now in the high class laboratories of the world. ${ }^{14}$

In the serum of patient generally enzyme-linked immunosorbent assays (ELISA) is a useful laboratory tool, for identifying the infection of hepatitis $\mathrm{C}$, with positive antibodies against the virus. Different serological test have been invented for detecting out antibodies against hepatitis $\mathrm{C}$ virus, with different generation and every step ahead given that lot of advantages with modifications inthe sensitivity of antibodiesagainst Hepatitis C Virus. Serological assays have several rewards in the analytical background, including little changeability and elevated compassion in screening, ease of automation and relative costeffectiveness. On the other hand serological assays have many weaknesses. On investigation of hepatitis $C$ patients with acute infection they build up symptoms merely in between fifty and seventy percent have quantifiable antibodies by moment, while approximately 90 percent will have quantifiable antibodies after a time about quarter year. ${ }^{14}$ Anti HCV antibodies indicates one of the three possibilities: past infectivity of HCV, Current active disease due to Virus of Hepatitis $\mathrm{C}$ and a fake response with positive result. The presence of current and past disease may be diagnosed thru serum tests thru antibody testing against virus of hepatitis $C$ but they don't confirm the presence of the virus and resolved infection in body at that time. ${ }^{13}$

There are the a number of issues with validity and specify of these tests, in the scenioro that a number of clinical diseases may present with a wrong laboratory interpretation in a minimum number of patients like diseases with autoimmune and newborn of mothers who are diseased with HCV chronically. Conversely reduced sensitivity attributed to fake risky outcome is mainly frequent especially before time after infection, which take one and half months for 3rd generation Enzymatic assays who give way helpful outcome against couple of days for Polymerase Chain Reaction and persons with disturbed immunity like HIV disease, patients on chemotherapy drugs or those who are availing hemodialysis. ${ }^{15}$ The benefits shown by advance laboratory testing to identify and measure RNA of HCV have made Polymerase Chain Reaction the method of choice for the direct identification of $\mathrm{HCV}$ in routine clinical laboratories. ${ }^{15}$

In 1989, study by Choo et al, from the time when the recognition and genetic description of the viral genome of $\mathrm{HCV}$, a range of analytic methods have been developed now-a-days. In patients' serum Enzymatic assays like ELISA are strongly helpful in the identification of viral infection of hepatitis $\mathrm{C}$ thru detection of antibodies against HCV. A 
series of first, second and third generations of serum tests for detecting antibodies against HCV have been launched and every recent test given that lot of good change regarding sensitivity for antibodies against HCV. ${ }^{16}$

Assays for serum analysis have lot of reward in the analytic background, together with simplicity of mechanization and apply comparative price value, and little changeability and elevated compassion in test. On other hand, serological assays have many drawbacks. ${ }^{16}$ The third generation ELISA test is easy to use and extremely accurate in favor of identification of viral infection due to Hepatitis $\mathrm{C}$, these are recommended as the only standard serological test to be used to make a diagnosis of chronic HCV infection. ${ }^{16}$

Polymerase chain reaction (PCR) testing is the most authentic laboratory test for dynamic viral infection due to Hepatitis $C$. in comparison to $3^{\text {nd }}$ generation ELISA, $2^{\text {nd }}$ generation is considered not as much of perceptive as third generation tests and instead they are additionally definite. The perception of $3^{\text {rd }}$ generation ELISA ranges more than ninety four to hundred percent, in comparison with Polymerase chain reaction. ${ }^{16}$

Lot of research studies had been carried throughout the world related to the diagnosis of chronic HCV infection by third generation ELISA and Polymerase Chain Reaction, but in Pakistan only some research has been carried locally. This study was conducted at Hepatitis Clinic, Peoples Medical College Hospital at Nawabshah (SBA) a tertiary care hospital attached with PUMHS (W) Nawabshah. This research was conducted for comparing difference between antibodies against Hepatitis C Virus through ELISA and Ribonucleic acid of Hepatitis C Virus through Polymerase Chain Reaction in the diagnosis of chronic HCV. One hundred patients included in our study were screened by antibodies against Hepatitis C Virus through ELISA and Ribonucleic acid of Hepatitis C Virus through Polymerase Chain Reaction. We have concluded that the results of our study are helpful in reducing the financial load, quick diagnosis, validity of ELISA and therefore will affect the morbidity and mortality towards the decline and will help in future research.

The purpose of our current research is to evaluate the positive outcome of the antibodies against Hepatitis C Virus through ELISA and Ribonucleic acid of Hepatitis C Virus through Polymerase Chain Reaction.

\section{METHODS}

100 patients were included in this research was included with positive antibodies against Hepatitis C Virus through ELISA and Ribonucleic acid of Hepatitis C Virus through Polymerase Chain Reaction, who attended the Hepatitis clinic Peoples Medical College Hospital Nawabshah from December 2015 to December 2016.

Subjects incorporated in our research were with positive antibodies against Hepatitis C Virus through ELISA and Age between 20 to 60 years.

Subjects who were excluded from our study include with decompensate Cirrhosis, Hepatocellular Carcinoma, above 60 years, on immuno-suppressive therapy or with contraindication to interferon therapy or with concomitant hepatitis B infection and Patients suffering from other systemic diseases e.g. connective tissue diseases, malignancies, or pancreatic disorders.

Patients selected were interviewed by using previously designed Performa regarding for age, residence, socioeconomic status, marital status, literacy background, clinical features, possible risk factors, co-morbid disease, all subjects went for laboratory investigations including antibodies against Hepatitis C Virus thru ELISA, and Ribonucleic acid of Hepatitis $C$ Virus through Polymerase Chain Reaction, SGPT, Blood CP and Ultrasonography of abdomen was done in all the patients to assess the liver status.

History was taken for transfusion of blood or blood products, intravenous drug abuse, sexual contact, hemodialysis, surgery, use of parental injections, shaving from barbers, sharing of things, and presence of hepatitis $\mathrm{C}$ in family members. Subjects found positive for antibodies against 
HCV incorporated with our study. Antibodies against HCV checked out by Enzymatic assay (ELISA) at PMCH Pathology laboratory. Simultaneously screening for surface antigen of Hepatitis B (HbsAg) was done for exclusion of patients suffering concomitant hepatitis $B$ virus infection.

\section{Statistical Methods}

Statistical Package for Social Sciences version 10.0 soft ware program used for Statistical analysis. Results were analyzed and compiled by calculating the mean \pm standard deviations (S.D), median with range for all continuous variables e.g. antibodies against Hepatitis C Virus through ELISA and Ribonucleic acid of Hepatitis $C$ Virus through Polymerase Chain Reaction and numbers for categorical data for example age, sex, risk factors for hepatitis $\mathrm{C}$, associations or co-morbid diseases. Uni-variate analyses were carried out by using the independent sample testing and Pearson chi square test where appropriate. Statistically P.value of $<0.05$ is considered significant.

\section{RESULTS}

\section{Demographic Data}

A total 100 patients were studied at Hepatitis Clinic Peoples Medical College Hospital Nawabshah. Out of 100 patients 54 male and 46 female were included in our study as shown in Figure-1. All patients included in our study were anti-HCV antibodies positive by ELISA third generation.

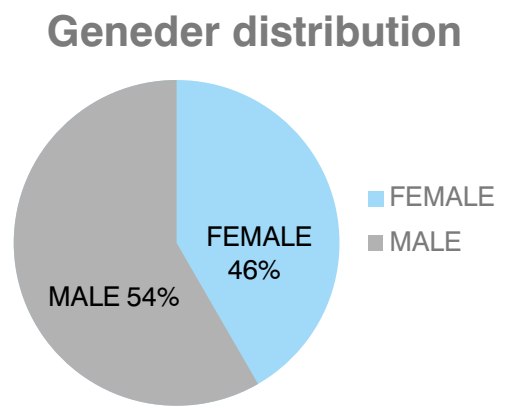

Figure-1. Gender distribution

Age series of patients started from minimum 20 and maximum 60 years. Mean age was 47.5 years $( \pm 13.4 \mathrm{yrs})$. Majority of the patients $(63 \%)$ were in the thirties and forties years and thus the greater part of subjects suffering from HCV were related with working age group. Figure-2 shows distribution of different age groups.

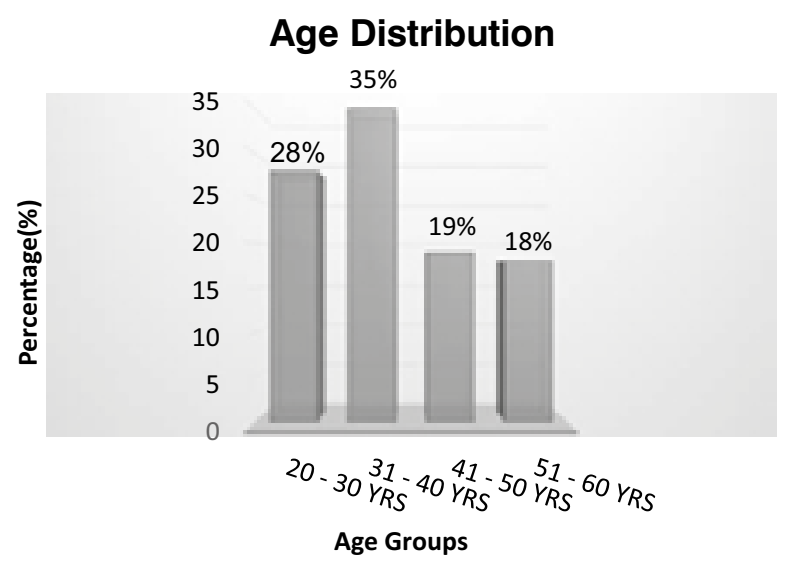

Figure-2. Distribution of age in groups

\section{RISK FACTORS FOR HEPATITIS C}

In our setup different hazard elements for HCV were also identified. Most of the patients have multiple risk factors. History of multiple parental injections were very high $87 \%$, sharing of things was seen in $84 \%$, most of the males $48(87 \%)$ out of 54 have shaving history from barbers, $41 \%$ have history of surgery, $33 \%$ have history of dental procedures. It was found that $32 \%$ had history of blood transfusion in their life, $6 \%$ had positive tattoo marks on the body at different positions (Figure-3).

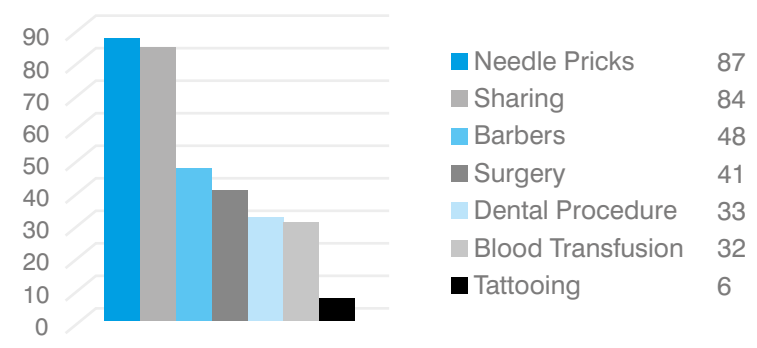

Figure-3. Risk factors of Hepatitis C

\section{Socio-Economic Status}

In our study most of patients were belonging to lower socio-economic class. Out of 100 cases $59(59 \%)$ were from lower socio-economic class, 39 from middle class and only $2 \%$ were from the upper class, this indicates that most of our poor population is suffering from the chronic $\mathrm{HCV}$ infection (Figure-4). 


\section{Occupation}

By occupation most of females in our study were house wives $41 \%$ also having low literacy rate. Only $19 \%$ persons were employed in Government sector, most were related to health department, as LHWs, dispensers, technicians and LHVs; 03\% were teachers and $02 \%$ from police department. Patients related to agriculture were $11 \%, 10 \%$ were laborers, 08\% patients were shopkeepers, $07 \%$ students and $07 \%$ were involved in private organizations representing different cultures (Figure-5).

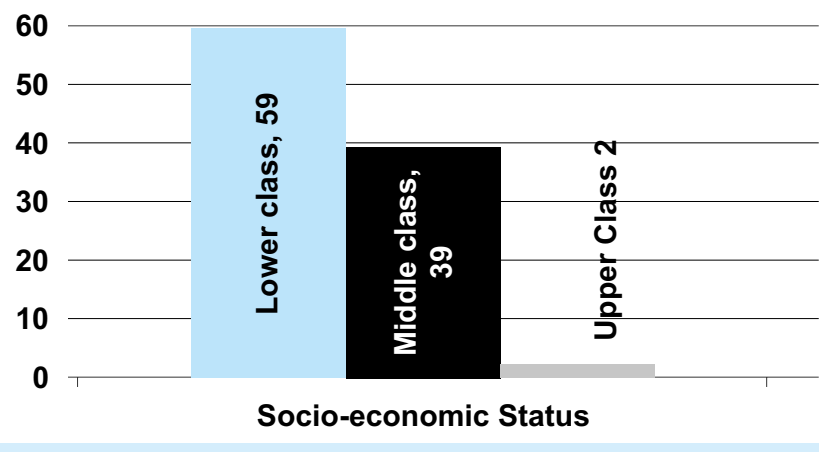

Figure-4. Socio-economic Status of patients. Occupational Status associated with HCV infection

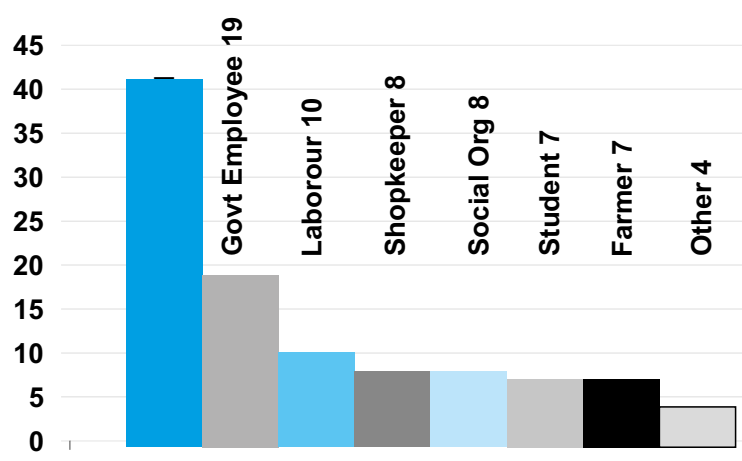

Figure-5. Occupational status of individuals

\section{Marital Status}

In our study 80 (80\%) patients were married, $18(18 \%)$ un-married and 2 (2\%) were widows (Figure-6).

\section{SERUM SGPT LEVELS}

Serum SGPT was analyzed in totally 100 subjects. SGPT (ALT) was normal in 19 (19\%) individuals, where as elevated in $81(81 \%)$ cases. In most patients there was rise in the level of ALT more than 2 double. The lowest values were $17 \mathrm{IU} / \mathrm{L}$ and highest was $534 \mathrm{IU} / \mathrm{L}$ (Figure-7).

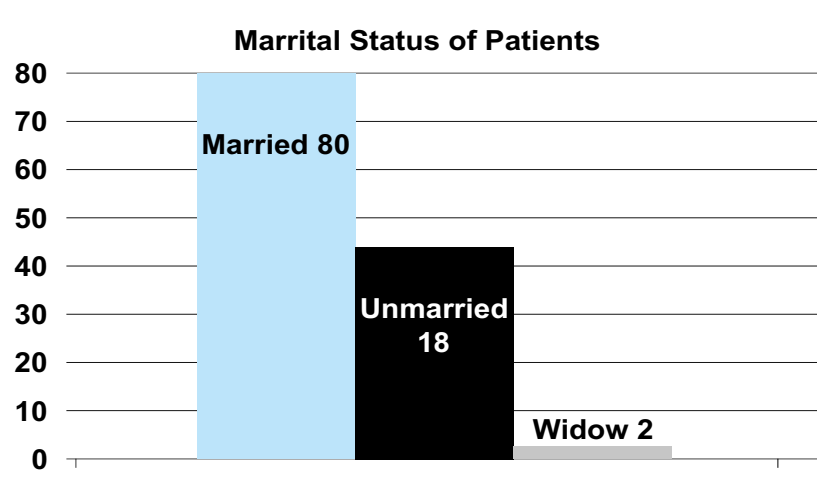

Figure-6. Marital status

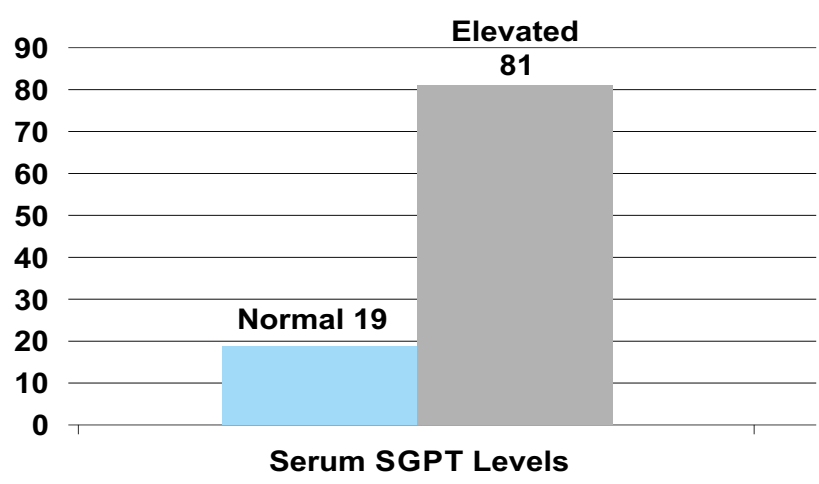

Figure-7. Serum SGPT (ALT).

\section{Hepatitis C Virus Ribonucleic acid}

In $98 \%$ subjects Hepatitis C Virus Ribonucleic acid was present and only in $2(2 \%)$ individuals Hepatitis C Virus Ribonucleic acid was not present. In those subjects whom antibodies titer against Hepatitis C Virus was very less (Anti-HCV weak positive) the Hepatitis $C$ Virus Ribonucleic acid was undetectable (Figure-8).

\section{HCV RNA Detection}

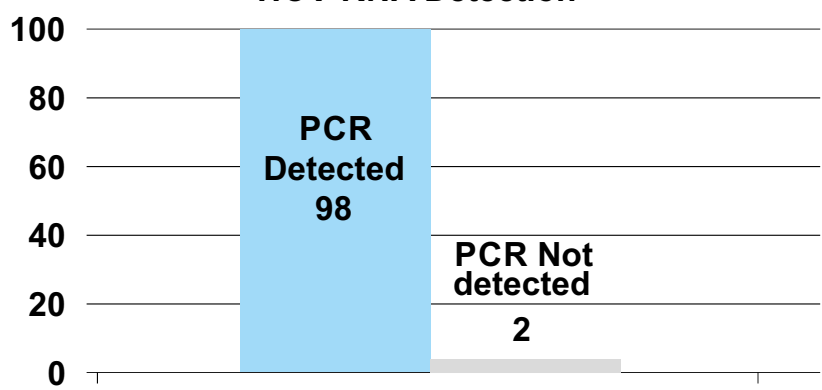

Figure-8. HCV RNA detection in Anti-HCV antibodies patients by ELISA

\section{DISCUSSION}

In relation to untimely identification of RNA, it depends upon the recognition of Hepatitis $C$ Virus genome analysesthruPCR, which is comparatively 
neither cost effective and nor easily accessible up to now in many different investigating institutes in Pakistan, so the confirmatory investigations related to Hepatitis C Virus RNA is frequently late in anticipation of antibody development against the HCV are evident after exposure. It takes approximately about 2 to 3 months for antibodies development, whereas in the serum after 2-5 weeks, the Virus of Hepatitis C thru RNA by PCR is evident. In addition to that in some immunocompromised people's serological analysis found to be problematical because of less capability to build up protective systemic reaction against viruses ${ }^{17-19}$ Recognition with quantification in relation to Hepatitis $C$ Virus genome has developed into a crucial prime element in favor of scientific investigations. Though analysis of medical testing information is inaccurate devoid of a floor of preceding information associated to the scientific restrictions of the Hepatitis $C$ Virus genome tests applied. Techniques to identify plus quantification of Hepatitis C Virus RNA must excist specific, perceptive, accurate and easily applicable repeatedly. ${ }^{20,21}$

Since the introduction of screening, majority of the steps has been taken to raise together validity in relation to assays for anti-HCV antibodies diagnosis many decades ago. The initial assays for diagnosis of HCV antibodies had significant boundaries particularly a elevated tempo of fake constructive and fake-unconstructive results. ${ }^{22}$ For augment of validity in available analytic testing a larger figure of determined $\mathrm{HCV}$ antigens recently incorporated preceding additional exact antibodies recognition. Now a day's different ELISA production from $1^{\text {st }}$ to $3^{\text {rd }}$ generation techniques are present in the standard laboratories. The $3^{\text {rd }}$ generation ELISA method detects antigens that are oblique by the recognized core and represent different parts of the Hepatitis C Viral genetic map. ${ }^{22}$

Nowadays patients who are affected by viral infection due to hepatitis $\mathrm{c}$ virus, $3^{\text {rd }}$ generation enzymatic assays are used for screening on large scale. HCV RNA is evident in approximately > 99\% of immuno-competent persons with positive enzymatic assays. On the other hand in persons who are markedly immuno-deficient regardless of Viral replication the investigations for screening may be unconstructive. ${ }^{23}$ To screen donors blood ELISA-3 is widely used and regardless that, there is increased specification of test $(99.7 \%)$, in which fake positive outcome might come about. ${ }^{23-24-25}$ significance of the investigation depends on the positive predictive in the population of prevalence of HCV antibodies. In patient's potentially immunocompromised undergoing dialysis, for detecting viremia PCR is the reliable test only. ${ }^{26}$ The most common method of assessing HCV infection is the serological diagnosis of anti HCV antibody at present. Although a positive result by ELISA and RIBA HCV indicates active HCV infection it does not distinguish between current infection and previous exposure. Direct detection of HCV would be more useful. Methodologies aimed at the direct detection of the HCV genome such as PCR are not cost effective and needs hard work for appropriate standardization. ${ }^{27-28}$ ELISA screening in reducing the risk of HCV transmission by blood transfusion in blood donors when considered in the reality is highly fruitful.

In patients who are sero-negative blood donors with normal $A L T$, in the latent infection, when virus is in and antibodies are not there, HCV can be transmitted during the this time without notice. This may last for months. ${ }^{27-28}$

In our study we included 100 cases of Anti-HCV antibodies positive by ELISA. Individuals were assessed for clinical features, risk factors and other criteria on the proforma. In present study out of 100 positive enzymatic assay patients with Antibodies against Virus of Hepatitis C, viral RNA was present in $98 \%$ of subjects. As per our study consequences 3rd generation enzymatic assays (ELISA) used for Antibodies against Virus of Hepatitis $C$ investigation is extremely perceptive.

In view of the fact that Hepatitis C, viral RNA was present in $98(98 \%)$ cases with high titers of Antibodies against Virus of Hepatitis $C$ positive patient's sera and negative in $02(2 \%)$ patients with low titer enzymatic assay in Antibodies against Virus of Hepatitis $C$ with patients. 
In a study conducted by Mevhibe $B$. et al, viral RNA was present in total hundred percent of subjects and absent in cases with undetectable nucleic acid with normal serum ALT levels. ${ }^{29}$ The validity of Antibodies against Virus of Hepatitis $C$ in the analysis of viral hepatitis $\mathrm{C}$ was hundred percent between patients with elevated S/CO ratio the possibility of viral nucleic acid positivity was straightforwardly associated with $\mathrm{S} / \mathrm{CO}$ ratio. This study also supports our study.

Payan et al. in their study have also shown a positive PCR in $98.1 \%$ subjects with anti-HCV positive by third generation ELISA with high $\mathrm{C} / \mathrm{O}$ ratios, ${ }^{30}$ their study also supports strongly our study results.

Another study done by Abdel-Hamid et al have shown the sensitivity of EIA 3 was $99 \%$, compared to $89.8 \%$ for the ELISA 2, while the specificity of ELISA 3 was $98.8 \%$, compared to $98.8 \%$ for the ELISA 2. These results show that the reliability of ELISA 3 in screening the sera sample is excellent and ELISA third generation can be used in the absence of additional tests where resources are at limits. ${ }^{31}$

Study conducted by Sayan et al analyzed that viral nucleic acid was absent in small concentration and positive antibodies against virus of Hepatitis $\mathrm{C}$ in the collected serum. Disagreement was prominent in past due to nonexistence of viral nucleic acid in a ratio of Antibodies against Virus of Hepatitis $C$ present in patients suffering from cirrhosis of liver. ${ }^{17}$ existence of a transformed Virus of Hepatitis $C$, previous contamination by Virus of Hepatitis $\mathrm{C}$ leads to change in the level of HCV RNA and that could be explained by the presence of antibodies against virus of Hepatitis C. Tropical areas produce hypergammaglobulinemia due to existence of several diseases, with possibility for fake constructive results might come about concurrently for antibodies against virus of Hepatitis C. ${ }^{17}$

Other immunological investigations for rechecking of serum with different methods are also suitable and cost-effective prior to apply investigations related to viral nucleic acid to confirm the subjects having little antibodies against virus of Hepatitis $C$ levels as a result. Though it is rare that after getting blood and its products, patient may get viral Hepatitis $\mathrm{C}$ contamination, if donor is collected in the latent phase of antibody development. ${ }^{20}$

Thru observation and analysis it has been assessed that important laboratory test considered being purpose for rapid analysis for confirmation and further treatment is RTPolymerase Chain Reaction for detection of viral RNA of Hepatitis C. Anti-HCV antibodies detection thru valid ELISA method is the test which is used as usual method and is secure and valid in favor of a blood and products donations for the reason that total of antibodies Against viral Hepatitis C unconstructive persons have undetected viral nucleic acid. Little concentration with optimistic antibodies against viral Hepatitis $C$ cases must be initially re-evaluated thru antibodies against viral Hepatitis $C$ immunological assays and for $C$ virus nucleic acid verification we need then PCR. ${ }^{20}$

It has been concluded in small frequency areas that fake optimistic immunological assays results have been documented and the accurateness of the $3^{\text {rd }}$ generation investigations is better in elevated frequency areas. For that reason additional investigations with a positive anti-HCV ELISA screen may be not necessary in high-risk patients.

A study by Pawlotsky and associates ${ }^{26}$ determined that a single test by ELISA 3 determination in favor of analysis of viral Hepatitis $C$ disease is sufficient in investigation settings and that for follow-up a repeated ELISA with RIBA was no longer recommended.

Thru investigation, it is analyzed among the immuno-compromised persons, the ratio of fake optimistic consequences with the $3^{\text {rd }}$ generation immunological assays are approximately fifteen percent. ${ }^{28}$ Therefore it is not necessary that person should solely depend on screening test with a detected antibodies against the virus of hepatitis $\mathrm{C}$ to assess that whether a patient is contaminated with Viral Hepatitis C infection or not. An optimistic selected investigation consequence is supposed to be confirmed with a self-determining additional 
Polymerase Chain Reaction tests that have the more specificity. ${ }^{28}$ mainly valid analysis for the analysis of Viral Hepatitis $\mathrm{C}$ disease is the through quantification from the blood of the infected patients. $^{32}$

Due to nonexistence of virus, the antibodies against the virus of hepatitis $\mathrm{C}$ may exist positive because of a past infection. In patients whose resistant system is compromise the proportion of fake titer of antibody existence is not as much of given that production of antibodies in these patients directs the occurrence of elevated viral load to excite their miserable defense structure. Sometimes because of detection of unclear antibodies existence by immunological assay selection investigations, the presence RT-RNA may be because of false positivity. ${ }^{33-34}$

\section{CONCLUSION}

It was concluded from the study that investigations carried out for the analysis and supervision of Viral Hepatitis $C$ disease, every one includes their own importance. Immunological assays have a lot of compensations in the analytic situation together with simplicity of mechanization, utilization, proportional cheapness, and little inconsistency with elevated compassion in viewing. The precision of $3^{\text {rd }}$ generation investigation is incredibly of elevated quality in eminent frequency areas. Therefore, additional investigations for diagnosis might not exist essential in elevated danger population having positive antibodies against the virus of hepatitis $C$ enzymatic immunological assay panel. Our study confirms that anti-HCV antibodies by ELISA $3^{\text {rd }}$ generation with high signal cut off patient values is as sensitive as PCR in the diagnosis of viral hepatitis $\mathrm{C}$ disease.

Copyright(C) 15 Sep, 2017.

\section{References}

1. Umer M, Iqbal M. Hepatitis $C$ virus prevalence and genotype distribution in Pakistan: Comprehensive review of recent data. World J Gastroenterol. 2016 Jan 28; 22(4): 1684-1700.Published online 2016 Jan 28. doi: 10.3748/wjg.v22.i4.1684.PMCID: PMC4721999.

2. Hajarizadeh B, Grebely J, Dore GJ. Epidemiology and natural history of HCV infection. Nat Rev Gastroenterol Hepatol. 2013; 10:553-62.

3. Lavanchy D. Evolving epidemiology of hepatitis C virus. Clin Microbiol Infect.2011; 17:107-15.

4. Williams IT, Bell BP, Kuhnert W, Alter MJ. Incidence and transmission patterns of acute hepatitis $C$ in the United States, 1982-2006. Arch Intern Med. 2011; 171:242-8.

5. Armstrong GL, Wasley A, Simard EP, McQuillan GM, Kuhnert WL, Alter MJ. The prevalence of hepatitis C virus infection in the United States, 1999 through 2002. Ann Intern Med. 2006; 144:705-14.

6. Delarocque-Astagneau E, Meffre C, Dubois F, Pioche C, Le Strat $Y$, Roudot-Thoraval $F$, et al. The impact of the prevention programme of hepatitis $\mathbf{C}$ over more than a decade: the French experience. J Viral Hepat. 2010; 17:435-43.

7. Duberg A, Janzon R, Bäck E, Ekdahl K, Blaxhult A. The epidemiology of hepatitis $C$ virus infection in Sweden. Euro Surveill. 2008; 13:18882.

8. Razali K, Thein HH, Bell J, Cooper-Stanbury M, Dolan K, Dore $\mathrm{G}$, et al. Modelling the hepatitis $\mathbf{C}$ virus epidemic in Australia. Drug Alcohol Depend. 2007; 91:228-35.

9. Chung $H$, Ueda $T$, Kudo $M$. Changing trends in hepatitis $\mathbf{C}$ infection over the past $\mathbf{5 0}$ years in Japan. Intervirology. 2010; 53:39-43.

10. Lavanchy D. The global burden of hepatitis C. Liver Int. 2009; 29 Suppl 1:74-81.

11. Moradpour D, Penin F, Rice CM. Replication of hepatitis C virus. Nat Rev Microbiol. 2007; 5:453-63.

12. WHO. Epidemic and pandemic alert and response, Hepatitis C virus. 2003, cited 2014-11. Available from: $\quad$ http://www.who.int/csr/disease/hepatitis/ whocdscsrlyo2003/en/index2.html.

13. Dufour $R$. Lot to lot variation in anti-hepatitis $\mathbf{C}$ signalto-cutoff ratio. Clin Chem. 2004; 50:958-60.

14. Ayaz $M$, Gretch D. Current and Future hepatitis $C$ virus diagnostic testing: problems and advancements. Microbes and Infection. 2002; 4:1227-36.

15. Strader D, Seeff L. Hepatitis C: A brief clinical overview. ILAR Journal. 2001; 42:107-16.

16. Abusedra A, Najam F, Elsherif M, Elbress R. Evaluation of the available anti-HCV antibody detection tests with RT-PCR assay, in the diagnosis of hepatitis C virus infection. Lib J Infec Dis. 2010; 4(1):41-5.

17. Marison G, Pirola R, Lacarini S, et al. Acute Hepatitis C. Australian Family Physician (Special Issue) 1999;28:46-50.

18. Pawlotsky JM. Diagnostic tests for hepatitis C. J 
Hepatol. 1999; 31:71-9.

19. Lavanchy D, Steinmann J, Moritz A, Frei PC. Evaluation of a new automated third-generation anti-HCV enzyme immunoassay. J Clin Lab Anal. 1996; 10:26976.

20. Choo QL, Kuo G, Weiner AJ, Overby LR, Bradley DW, Houghton $M$. Isolation of a cDNA clone derived from a blood-borne non-A, non-B viral hepatitis genome. Science. 1989; 244(4902):359-62.

21. Bukh J, Wantzin P, Krogsgaard K, Knudsen F, Purcell RH, Miller $\mathrm{RH}$. High prevalence of hepatitis $\mathbf{C}$ virus (HCV) RNA in dialysis patients: Failure of commercially available antibody tests to identify a significant number of patients with HCV infection. Copenhagen Dialysis HCV Study Group. J Infect Dis. 1993; 168:13438.

22. Kleter GE, Dooran LJ, Brouwer JT, Schalm SW, Heijlink RA, Quint WG. Sequence analysis of the 5' untranslated region in isolates of at least four genotypes of hepatitis $\mathbf{C}$ virus in the Netherlands. $\mathbf{J}$ Clin Microbial. 1994; 32:306-10.

23. Pawlotsky JM. Use and interpretation of virological tests for hepatitis C. Hepatology.2002; 36:65s-73s.

24. Simmonds P, McOmish F, Yap PL, Chan SW, Lin CK, Dusheiko $G$, et al. Sequence variability in the 5 ' non - coding region of hepatitis $C$ virus: Identification of a new virus type and restrictions on sequence diversity. J Gen Virol. 1993; 74: 661-8.

25. Bukh J, Purcell $\mathrm{RH}$, Miller $\mathrm{RH}$. Importance of primer selection for the detection of hepatitis $C$ virus RNA with the polymerase chain reaction assay. Proc Natl Acad Sci USA. 1992; 89:187-91.

26. Pawlotsky JM, Lonjon I, Hezode C, Raynard B, Darthuy F, Remire J, Soussy CJ, Dhumeaux D.et al. What strategy should be used for diagnosis of hepatitis C virus infection in clinical laboratories? Hepatology. 1998; 27:1700-02.

27. Martins RM, Vandenborght BO, Rouzere CD, Santana
CL, Mori DN, Ferreira RG, Yoshida CF, et al. Anti-HCV related to HCV PCR and risk factors analysis in a donor population of Central Brazil. Rev Inst Med Trop. Sao Paulo. 1994; 36:501-6.

28. Alter MJ, Kuhnert WL, Finelli L. Centers for Disease Control and Prevention. Guidelines for laboratory testing and result reporting of antibody to hepatitis C virus. Centers for Disease Control and Prevention. MMWR 2003; 52:1-13,15.

29. Balk M, Saydam G, Cengiz D, Turkmen A, Sisek H, Himmetoglu T. The Utility of anti-HCV S/CO Ratio, HCV-RNA and ALT test in predicting viremia in antiHCV positive patients. Turk J Biochem. 2007; 32(2):514.

30. Payan C, Raimbert A, Fouchard-Hubert I, Kouyoumdjian S, Lunel-Fabiani F. Quantitative antibody analysis: use for the diagnosis of hepatitis $\mathbf{C}$ virus chronic infection Ann Biol Clin (Paris). 2003; 61(3):311-7.

31. Abdel-Hamid M, Ei-Daly M, El-Kafraway S, Mikhail N, Strickland GT, Fix AD. Comparison of second and thirdgeneration enzyme immunoassays for detecting antibodies to hepatitis $\mathbf{C}$ virus. J Clin Microbiol. 2002; 40(5):1656-9.

32. Schiff ER, de Medina M, Kahn RS. New perspectives in the diagnosis of hepatitis C. Semin Liver Dis.1999; 19:3-15.

33. Furusyo N, Hayasi J, Kanamoto- Tanaka Y, Ariyama I, Etoh $\mathrm{Y}$, Shigematsu $\mathrm{M}$, et al. Liver damage in hemodialysis patients with hepatitis $\mathbf{C}$ virus viremia: $A$ prospective 10 year study. Dig Dis Sci.2000; 45:2221-8.

34. Sancez-Quijano A, Andreu J, Gavilan F, Luque F, Abad MA, Soto $B$, et al. Influence of human immuno deficiency virus type1 infection on the natural course of chronic parenteral acquired hepatitis C. Eur J clin Microbiol Infect Dis.1995; 14(11):949-53.

\begin{tabular}{|l|l|l|}
\hline \multicolumn{3}{|c}{ AUTHORSHIP AND CONTRIBUTION DECLARATION } \\
\hline Sr. \# & \multicolumn{1}{|c|}{ Author-s Full Name } & Contribution to the paper \\
\hline 1 & Ghulam Mustafa Jamali & Introduction \& Data collection \\
\hline 2 & Anwar Ali Jamali & Data analysis, Result, Analysis \\
\hline 3 & Habibullah Shaikh & Discussion
\end{tabular}

